\title{
The long-Run and Short-Run Analysis between Stock Market Index and Macroeconomic Variables in Jordan: Bounds Tests Approach
}

\author{
Raed Walid Al-Smadi ${ }^{1}$, Muthana Mohammad Omoush ${ }^{2}$ \\ ${ }^{1}$ Department of Finance and Economics Science, Irbid National University, Irbid, Jordan \\ ${ }^{2}$ Department of Tourism Management, Irbid National University, Irbid, Jordan \\ Correspondence: Raed Walid Al-Smadi, Department of Finance and Economics Science, Irbid National \\ University, Irbid, Jordan.
}

Received: January 2, 2019

Accepted: January 16, 2019

Online Published: March 13, 2019

doi:10.5539/ibr.v12n4p50

URL: https://doi.org/10.5539/ibr.v12n4p50

\begin{abstract}
This paper investigates the long-run and short-run relationship between stock market index and the macroeconomic variables in Jordan. Annual time series data for the 1978-2017 periods and the ARDL bounding test are used. The results identify long-run equilibrium relationship between stock market index and the macroeconomic variables in Jordan. Jordanian policy makers have to pay more attention to the current regulation in the Amman Stock Exchange(ASE) and manage it well, thus ultimately helping financial development.
\end{abstract}

Keywords: stock market index, macroeconomic variables, ARDL bounding test, Amman Stock Exchange

\section{Introduction}

Over the past decades, the relationship between stock markets index (SMI) and macroeconomic variables has been researched in developed and developing countries (Hossain et al., 2013; Rangel, 2011; Rahman et al., 2009). Moreover, stock markets play an important role in economic growing through transferring available funds from savings units to borrowings units (Naik and Padhi, 2012; Pal and Mittal, 2011). Thus, both of financial and economic theories argued that stocks prices are affected by the performance of main macroeconomic variables (Bekhet and Matar, 2013; Ross, 1976; Fama, 1970; Sharpe, 1964).

Furthermore, the financial market affects economic growth by the efficient financial systems (e.g., banks, equity markets and bond markets), which are the channels of capital and their benefits for economic growth (Khan et al., 2014;Otchere, Soumare and Yourougou, 2011). Also, the financial market plays a significant role in economic growth. It promotes economic growth through capital accumulation and technological advancement by boosting savings rate, delivering information about investments, optimizing the allocation of capital, mobilizing and pooling savings, and facilitating and encouraging foreign direct investment(FDI). Besides, financial development may contribute to economic growth through mobilized savings that increases the volume of resources available to finance investment (Bekhet and Al-Smadi, 2017).

Moreover, the finance literatures contain huge number of studies that examined the long-run and short-run relationship between SMI and macroeconomic variables (GDP, exchange rate (EX), broad money supply (M2), industrial production (IP), consumer price index (CPI) and FDI). Their results supported evidence of long-run and short-run relationship among the variables(Bekhet and Matar, 2013; Bekhet and Mugableh, 2012;Kumar, 2011; Rangel, 2011;KarimandMajid, 2010;Chen, 2009; Ibrahim and Aziz, 2003).Thus, the main objective of this paper is to examine the long run and short run linkages betweenthe SMI and (GDP, M2, IP, CPI and FDI).This provides a clear picture for the policy makers in formulating efficient economic policies in financial market by the efficient financial systems (e.g., banks, equity markets and bond markets). Section 2 provides the overview of Jordanian economic and stock market. The literature review is presented in section 3. Data and model are presented in section 4. The economic framework, results and conclusion are discussed in sections 5, 6 and 7 respectively.

\section{Overview of Jordanian Economy and Stock Market}

Jordanian economic performance fluctuated during the 1978-2016 period as a result of political, economic and social volatility of the region, which had a significant impact on the Jordanian economy by taking the form of economic shocks (World Bank, 2000, 2008, 2013). For example, the budget deficit and the balance of payments 
rose to the highest levels, foreign exchange reserves declined and the foreign debt situation worsened. The result was that the Jordanian dinar fell from USD 2.95 in 1982 to USD 1.70 in 1989. Also in 1984, the Jordanian RGDP decreased from 10\% annual growth in 1980 down to 6\% (Amranews, 2012; Wilson, 2005; World Bank, 2000). Also, the Jordanian economy has been subjected to many shocks since 2007, starting with the global financial crisis in the 2008-2010 period, Arab spring, interruption of Egyptian gas, and the Syrian crisis (Central Bank of Jordan(CBJ), 2013;Bekhet and Matar, 2013; World Bank, 2013).

However, the Jordanian government attempted to address the economic shocks through implementation several economic policies starting with internal policies represented by the economic planning since early (1976 to 2016) period and the external policies incorporated in the international economic agreements.Jordan became a member of the main international organizations in the world. For example, Jordan joined the World Trade Organization (WTO) in June 2000, the United States Free Trade Agreement (USFTA) in 2000 and the Greater Arab Free Trade Agreement (GAFTA) in 1998. More recently, Jordan signed a free trade agreement with Canada at the end of 2011. As a result the Jordanian economy became the most significant market in the Middle East (Ministry of Industry and Trade, 2012; Rosen, 2004).

Since economic growth is measured as the annual change of RGDP, it is important to reanalyse the Jordanian RGDP to show the performance of Jordanian economy activities. Generally, Jordanian RGDP at constant prices achieved stable performance for the 2013, 2014 and 2015 periods with an annual growth rate of $2.8 \%, 3 \%$ and 2.3\%, respectively (World Bank, 2016; CBJ, 2013).Figure1 shows that Jordanian RGDP at constant prices recorded an annual growth rate of $4.1 \%$ for the 1978-2016period.

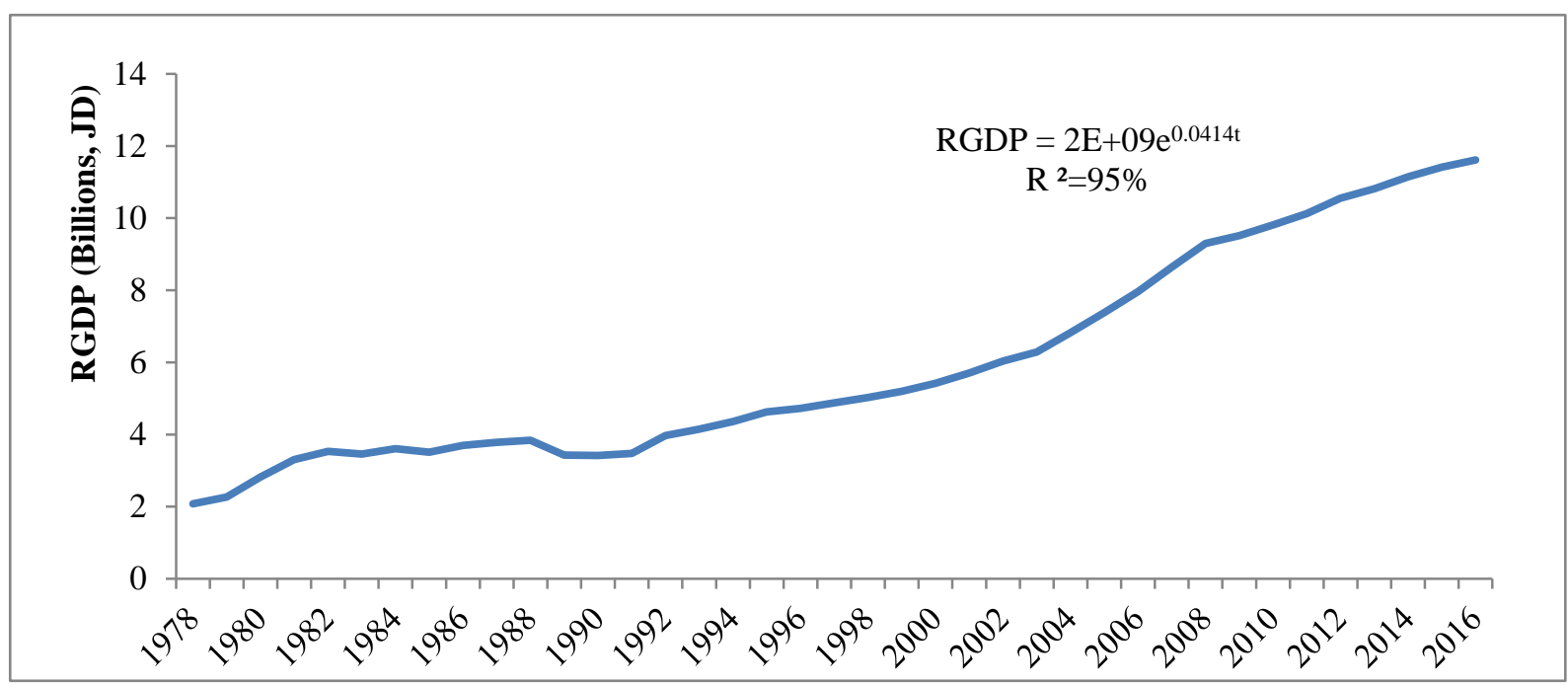

Figure 1. Jordanian RGDP for the (1978-2016) Period

Source: World Bank (2017)database, available online at:http://data.worldbank.org/country/jordan, accessed on Jan 2017.

Figure 1 represents that Jordanian RGDP started in 1978 with a value of JD 2.07 billion and increased to JD 3.84 billion in 1988. Due to the 1991 Gulf War and instability in the Middle East region, Jordanian RGDP was greatly affected. These conflicts caused massive resource shortages in the Jordanian economy, limited economic relations with other neighbour countries and reduced the recruitment of Jordanian workers. Besides, there was a decrease in the inward oil supply and a decline in the traditional Jordanian export markets (Bekhet and Matar, 2011). As a result of these conflicts, Jordanian RGDP decreased from JD 3.840 billion in 1988 to JD 3.470 billion in 1991. However in 1992, Jordanian RGDP improved again to reach JD 3.97 billion and continued increasing to reach JD 5.42 billion, JD 8.64 billion, JD 10.120 billion, JD 10.553 billion and JD 11.61 billion in 2004, 2007, 2011, 2012 and 2016, respectively.

In the long term history, Jordan's economy has been geared towards a free market economy, mainly through a policy of openness and activation of the leadership role of the private sector. Jordan has adopted a series of privatizations of enterprises owned by the state, and the most important step taken was restructuring the investment rules that led to encouraging the business environment. As a result, Jordan was ranked 111 of 183 countries that were studied in attractiveness to businesses in the world (IMF, 2011). Also, Jordan is classified as one of the top twenty countries in the world in terms of attracting FDI inflows (UNCTAD, 2012). Moreover, 
Jordan has witnessed structural reforms for the last 15 years including privatization of state enterprises, liberalization of the trade and investment administrative, introduction of modern regulations, and institutions, which have helped transforming the Jordanian economy into one of the most open economies in the Middle East Countries ((Jordan Investment Board, 2012; Bekhetand Al-Smadi, 2015).

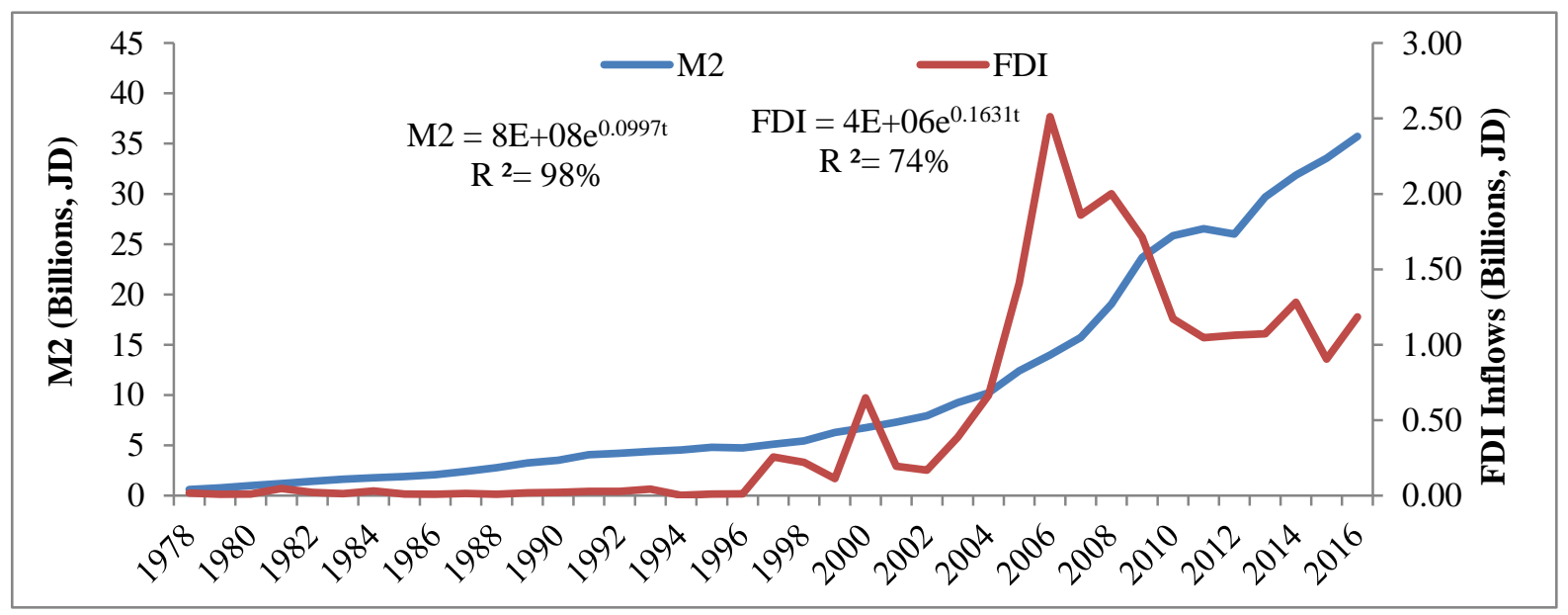

Figure 2. Jordanian FDI inflows and M2 for the (1978-2016) Period

Source: World Bank (2017)database, available online at:http://data.worldbank.org/country/jordan, accessed on Jan 2017.

Figure 2 shows that inward of FDI in 1978 started with JD17.2 Million and increased dramatically to the end of 2006 with a value of JD2.512 Billion. In 2011 the value of FDI inflows declined by $40 \%$ with a value of JD1.046Billion. However, this decline in the total investments was due to the current political instability and security environment in the Middle East, which limited capital flow between countries in the region and prompted investors to review their investment strategies (Bekhet\& Al-Smadi, 2012). In 2012 FDI inflows to Jordan has been increased to reach JD1.28 Billion then decline to reached 905.1 Million in 2015.

Moreover, the value of the money supply (M2) at constant prices recordeda decreasedvalue by $3.4 \%$ in 2012 comparedwith $8.1 \%$ and11.5\% in 2011 and 2010, respectively(CBJ, 2013). M2 is one important factor of the economic growth, which means that the rate of growth in M2 came as a result of the growth in GDP (Al-Bdour and Ahmad, 2012). Moreover, Figure 2 shows that the Jordanian M2 at constant prices achievedan annual growth rate of $9.9 \%$ for the 1978-2016period. However, the M2 in Jordan continued an upward trend over the 2002-2016 period with an average annual growth rate of 6.1\% to reach JD 35 billion at the end of 2016 (CBJ, 2012). The rise of $M 2$ came as a result of expansion in both domestic assets and net foreign assets that ultimately led to increase the GDP during the same period.

The Amman financial market was created and started its business in 1978. It served as the precursor to the Amman Stock Exchange (ASE). The ASE was established as a non-profit, private institution with administrative and financial autonomy (Allahawiah and Al-Amro, 2012; ASE, 2012). In addition, since 2007, Jordan has had full membership in the World Federation of Exchanges (WFE) and has been represented on the board of international accounting standards (Bekhet and Matar,2013).

Therefore, theSMIrecorded an annual growth rate of 6.1\% for the 1978-2016period. The performance oftheSMI fluctuated from 757 pointsin 1980 to 1,330 points in 2000 . These fluctuations were a result of the weakness of the monetary policy during theperiod of 1980-2000. However, the SMI started to increase with a value of 2,615 points in 2003 and reached the first peak in 2005 with 8,191 points, and then declined to reach 4,069 points in 2016 (Figure 3). 


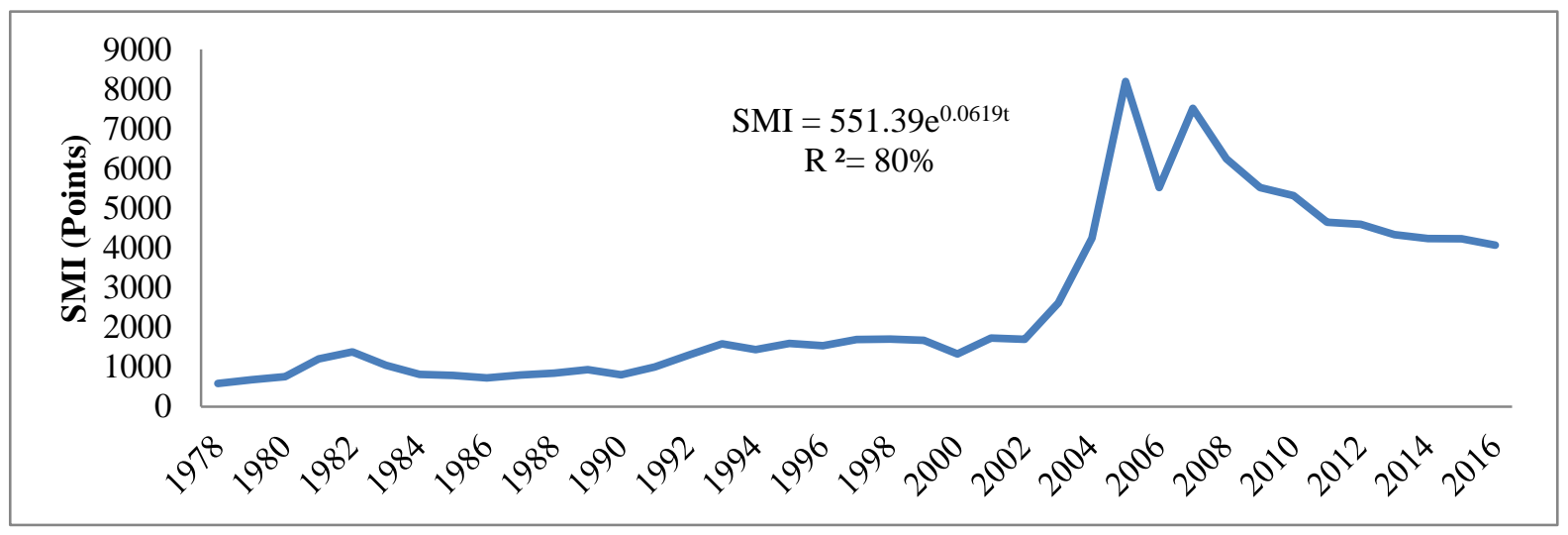

Figure 3. Stock Market Index for the (1978-2016) Period

Source: ASE (2013), available on line at: http://www.ase.com.jo/en/major-financial-indicators, Accessed on 2-7-2013

Besides, new monetarypolicywas adoptedin the ASEsince 2000; for example, it implemented an electronic trading system in March 2000 to increase the efficiency in the securities market. This system created a suitable environment for trading and led to a rise of the ASE performance (Bekhet and Al-Smadi, 2015).

\section{Literature Review}

Many studies confirmed that the financial development plays a significant role in economic growth. Also, the size of financial market contribute to economic many advantages through capital accumulation and technological advancement by boosting savings rate, delivering information about investments, optimizing the allocation of capital, mobilizing and pooling savings, and facilitating and encouraging FDI (Sghaier and Abida, 2013; Hassan et al., 2011; McKinnon, 1973). However, the relationship between SMI and macroeconomic variables (GDP, FDI, M2, IP, CPI and EX) has been investigated in many empirical studies (e.g., Bekhet and Matar (2013) for Jordan, Bekhetland Mugableh (2012) for Malaysia, Kyereboah, and Agyire, (2008) for Ghana, Li, Iscan, and Xu (2010) for Canada and the United States, Mansor., Ibrahim and Hassanuddeen Aziz (2003) for Malaysia). All these studies have confirmed the significant relationship between SMI and macroeconomic variables.

Some researchers examined the causality between financial market and economic growth. For example,in India and China,Padhan(2007) examined the causality linkages between SMI and economic activity in India, using a Granger causality test for the 1976-2005 period. This study confirmed that there is direction of causality among SMI and the macroeconomic variables. Shan (2003) investigated the relationship between economic growth and financial market in China, using a Granger causality test for the 1978-2001 period. The results showed that there is bi-directional causality between financial market and economic growth. And these studies are confirmed that the well-developed stock market could enhance economic activity.

In South Korea, Hong Kong and the UK,Chaiechi (2012) have studied the relationship between the SMI and macroeconomic variables using quarter time series data for the 1990-2006 period. The results showed that the financial market indicators contributed as expected in improving macroeconomic performance of the South Korean economy. SMI and domestic credit availability are strongly responsible for stimulation of investment, saving and productivity growth in Hong Kong. Also, the UK financial system seems vulnerable to future shocks, whether by shocks in the credit markets or stock markets.

Besides, Caporale, Rault, Sova and Sova (2009) explored the relationship between financial market and economic growth in ten new EU members by estimating a dynamic panel model for the 1994-2007 period. The results showed that the SMI and credit markets are still underdeveloped in these economies. Also, the results of this study are confirmed that there is direction of causality running from SMI to economic growth.

Furthermore, in many other countries in Asian (Philippines, Malaysia, Indonesia, Korea, India, Singapore, Thailand, Taiwan, China and Japan), Hsueh, Hu and Tu (2013) examined the relationship between financial development and economic growth using a panel data causality approach for the 1980-2007 period. This study has confirmed that there is uni-directional of causality between financial market and economic growth. Also, this study has found unidirectional Granger causality from financial market to economic growth in the cases of Malaysia, Indonesia, Korea, Singapore, Thailand, Taiwan and China.

In general, many other study have examined the relationship between macroeconomic variables and stock market 
indices using time series model and confirmed that the that macroeconomic variables significantly change stock market indices (See,..., Bekhet and Mugableh; Agrawalla and Tuteja, 2008;Buyuksalvarci and Abdioglu, 2010;Hosseini et al., 2011;Patra and Poshakwale, 2006; Wong et al., 2006).As discussed above the existing literatures, there are given conflicting results about the relationship between SMI and the variables of the current study (i.e., GDP, FDI, M2, IP, CPI, EX). Thus, to achieve the objectives of the current paper, it could be formulating the following hypotheses:

$\mathrm{H}_{1}$ : There are significant long-runequilibrium relationshipsbetween SMI and (i.e., GDP, FDI, M2, IP, CPI, EX) in Jordan.

$\mathrm{H}_{2}$ : There are significant short-run equilibrium relationships between SMI and (i.e., GDP, FDI, M2, IP, CPI, EX) in Jordan

\section{Data Sources and Model Specification}

Annual time series data was used and collected for the (1978-2017) period. However, it was obtained from different sources. SMI were collected from the ASE database (http://www.ase.com.jo). The (GDP, FDI and M2) variables were collected from the World Bank (http://www.worldbank.org). The (IP, CPI, EX) variables were selected from CBJ database (http://www.cbj.gov.jo).Furthermore, all the variables transformations into natural logarithmic (L) to reduce the hetrosecedasticity problem and to obtain the growth rate of the variable (Bekhet and Al-Smadi, 2017; Bekhet and Matar, 2012b; Montgomery et al., 2008; Chen et al., 1986), except EX to make this variable simultaneous with other variables (Bekhet and Mugableh, 2012). This study used Micro-fit 4.1 and E-views 7.2 statistical packages for analysis.Thus, followed the empirical literature, it is plausible to form the long-run, short-run as in Equation (1):

$$
\mathrm{LSMI}_{\mathrm{t}}=\mu+\alpha_{1} \mathrm{LGDP}_{\mathrm{t}}+\alpha_{2} \mathrm{LFDI}_{\mathrm{t}}+\alpha_{3} \mathrm{LM}_{\mathrm{t}}+\alpha_{4} \mathrm{LIP}_{\mathrm{t}}+\alpha_{5} \mathrm{LCPI}_{\mathrm{t}}+\alpha_{6} \mathrm{EX}_{\mathrm{t}}+\varepsilon_{\mathrm{t}}
$$

where $\mu$ is the intercept, $t$ is the time period, while $\varepsilon$ stands for a residual or error term that is assumed to be normally distributed and $\alpha_{\mathrm{i}} \mathrm{s}(\mathrm{i}=1, \ldots, 6)$ are the coefficients of the variables.

\section{Econometric Framework}

Several studies confirmed that if the time series data are not stationary, the regression analysis would not be true or spurious regression (Bekhet, Yasmin and Al-Smadi, 2017; Gujarati and Porter, 2009). Also, the choosing the appropriate time-series model depends on the results of stationarity and co-integration tests (Bekhet and Matar, 2013; Pesaran et al., 2001). However, in the current study the augmented Dickey-Fuller (ADF) [1979,1981] and Phillips-Perron (P-P) [1989] and Kwiatkowski, Phillips, Schmidt and Shin (KPSS) [1999] statistical tests are used to detect the level of stationarity either at I(0), I(1) or I(d) to selected the appropriate time-series model.

To achieve the objectives of the current study, the Autoregressive Distributive Lag (ARDL) bounds testing model, developed by Pesaran et al. (2001) is utilized. This model facilitates testing for the existence of relationships between variables at various levels of stationary data $\mathrm{I}(0)$ and $\mathrm{I}(1)$ or both; it presents better results for a small sample data set as compared to other techniques for co-integration (see also Pesaran and Shin, 1999). Furthermore, it is an unrestricted error correction model (UECM), it can take the appropriate lag selection which can specify the framework from general to specific without losing any long-run information, and can help to eliminate the problem of serial correlation and endogenous variables (Hamdi et al., 2014; Chandran and Munusamy, 2009; Pesaran and Shin, 1999).Generally, the variables will be co-integrated if they have a long-run or equilibrium relationship among each other (Bekhet and Mugableh, 2012). Thus, to examine the long run relationship between SMI and the variables of the current study (i.e., GDP, FDI, M2, IP, CPI, EX) ARDL model could be formulated as in Equation. (2).

$\left[\begin{array}{l}\Delta L S M I \\ \Delta L G D P \\ \Delta L F D I \\ \Delta L M 2 \\ \Delta L I P \\ \Delta L C P I \\ \Delta E X\end{array}\right]_{t}\left[\begin{array}{l}\alpha_{1} \\ \alpha_{2} \\ \alpha_{3} \\ \alpha_{4} \\ \alpha_{5} \\ \alpha_{6} \\ \alpha_{7}\end{array}\right]+\left[\begin{array}{lllllll}\eta_{11} & \eta_{12} & \eta_{13} & \eta_{14} & \eta_{15} & \eta_{16} & \eta_{17} \\ \eta_{21} & \eta_{22} & \eta_{23} & \eta_{24} & \eta_{25} & \eta_{26} & \eta_{27} \\ \eta_{31} & \eta_{32} & \eta_{33} & \eta_{34} & \eta_{35} & \eta_{36} & \eta_{37} \\ \eta_{41} & \eta_{42} & \eta_{43} & \eta_{44} & \eta_{45} & \eta_{46} & \eta_{47} \\ \eta_{51} & \eta_{52} & \eta_{53} & \eta_{54} & \eta_{55} & \eta_{56} & \eta_{57} \\ \eta_{61} & \eta_{62} & \eta_{63} & \eta_{64} & \eta_{65} & \eta_{66} & \eta_{67} \\ \eta_{71} & \eta_{72} & \eta_{73} & \eta_{74} & \eta_{75} & \eta_{76} & \eta_{77}\end{array}\right]\left[\begin{array}{l}\boldsymbol{L S M I} \\ \boldsymbol{L G D P} \\ \boldsymbol{L F D I} \\ \boldsymbol{L M 2} \\ \boldsymbol{L I P} \\ \boldsymbol{L C P I} \\ \boldsymbol{E X}\end{array}\right]_{t-1}+\left[\begin{array}{l}\varepsilon_{1} \\ \varepsilon_{2} \\ \varepsilon_{3} \\ \varepsilon_{4} \\ \varepsilon_{5} \\ \varepsilon_{6} \\ \varepsilon_{7}\end{array}\right]_{t}$

where, $\Delta$ is the first difference operator, $\alpha$ is represent the intercepts, $\eta_{\mathrm{ijj}} \mathrm{s}$ denote the long-run coefficients of the 
variables, $\varepsilon_{\mathrm{it}} \mathrm{s}$ denote the error terms that are normally distributedand $\mathrm{i}, \mathrm{j}=1, \ldots ., 7$.

However, the $\mathrm{H} 0$ of no co-integration is tested by applying the bounds F-statistics value, $\mathrm{H}_{0}: \eta_{\mathrm{ij}} \mathrm{s}=0$. The decision rule is based on comparing the calculated F-statistics value with the critical values tabulated in statistical tables (Pesaran and Pesaran, 2009). The co-integrationdecision rules are:

(1) If the calculated F-statistics value are greater than the upper bounds value, I(1), the null hypotheses, $\mathrm{H}_{0}: \eta_{\mathrm{ij}} \mathrm{s}$ $=0$, no co-integration, would be rejected. This means that all the variables included in the models have a long-run relationships whit each other.

(2) If the calculated F-statistics value falls below the lower bounds value, $I(0)$, the $\mathrm{H}_{0}: \eta_{\mathrm{ij}} \mathrm{s}=0$, are accepted. Thus, the variables included in the models do not share long-run relationships among themselves.

(3) If the calculated F-statistics value falls in the range $I(0) \leq$ F-statistics value $\leq I(1)$, the decisions are inconclusive to either accept or reject the long-run relationship.

Finally, equation (3) shows the mathematical form toobtain the short-run dynamic parameters and estimating the error correction model $\left(\mathrm{ECM}_{\mathrm{t}-1}\right)$ associated with the short-run estimates (Pesaran et al., 2001).

$\left[\begin{array}{l}\Delta L S M I \\ \Delta L G D P \\ \Delta L F D I \\ \Delta L M 2 \\ \Delta L I P \\ \Delta L C P I \\ \Delta E X\end{array}\right]_{t}\left[\begin{array}{l}\theta_{1} \\ \theta_{2} \\ \theta_{3} \\ \theta_{4} \\ \theta_{5} \\ \theta_{6} \\ \theta_{7}\end{array}\right]+\sum_{s=0}^{k} \Delta\left[\begin{array}{lllllll}\Pi_{11} & \Pi_{12} & \Pi_{13} & \Pi_{14} & \Pi_{15} & \Pi_{16} & \Pi_{17} \\ \Pi_{21} & \Pi_{22} & \Pi_{23} & \Pi_{24} & \Pi_{25} & \Pi_{26} & \Pi_{27} \\ \Pi_{31} & \Pi_{32} & \Pi_{33} & \Pi_{34} & \Pi_{35} & \Pi_{36} & \Pi_{37} \\ \Pi_{41} & \Pi_{42} & \Pi_{43} & \Pi_{44} & \Pi_{45} & \Pi_{46} & \Pi_{47} \\ \Pi_{51} & \Pi_{52} & \Pi_{53} & \Pi_{54} & \Pi_{55} & \Pi_{56} & \Pi_{57} \\ \Pi_{61} & \Pi_{62} & \Pi_{63} & \Pi_{64} & \Pi_{65} & \Pi_{66} & \Pi_{67} \\ \Pi_{71} & \Pi_{72} & \Pi_{73} & \Pi_{74} & \Pi_{75} & \Pi_{76} & \Pi_{77}\end{array}\right]_{s}\left[\begin{array}{l}\Delta L S M I \\ \Delta L G D P \\ \Delta L F D I \\ \Delta L M 2 \\ \Delta L I P \\ \Delta L C P I \\ \Delta E X\end{array}\right]_{t-s}\left[\begin{array}{l}\lambda_{1} \\ \lambda_{2} \\ \lambda_{3} \\ \lambda_{4} \\ \lambda_{5} \\ \lambda_{6} \\ \lambda_{7}\end{array}\right]_{s}\left[\begin{array}{l}E C M_{1} \\ E C M_{2} \\ E C M_{3} \\ E C M_{4} \\ E C M_{5} \\ E C M_{6} \\ E C M_{7}\end{array}\right]_{t-1}+\left[\begin{array}{l}\varepsilon_{1} \\ \varepsilon_{2} \\ \varepsilon_{3} \\ \varepsilon_{4} \\ \varepsilon_{5} \\ \varepsilon_{6} \\ \varepsilon_{7}\end{array}\right]_{t}$

where $\Delta$ is the first difference operator, $\theta_{\mathrm{i}} \mathrm{s}$ represents the intercepts, $\Pi_{\mathrm{ij}} \mathrm{s}$ denote the short-run coefficients; $\lambda_{\mathrm{i}} \mathrm{s}$ represents the coefficients of the error correction model $\left(\mathrm{ECM}_{\mathrm{t}-1}\right)$ that are used tolink the long-run and short-run equilibrium among the variables; $k$ represents the lag length; $s$ is the lag order and $i, j=1, \ldots \ldots ., 7$.

\section{Empirical Results}

\subsection{Data Quality, Stationarity and Co-integration Results}

Table 1 shows the quality data testing and interrelationship matrix results. The results show that all the study variables LSMIt, LGDPt, LFDIt, LM2t, LIPt, LCPIt and EXt are normally distributed with zero mean and constant variance (Ets $\sim \mathrm{N}(0, \sigma 2)$ ). These results are confirmed by Skewness and Jarque-Bera normality tests. The results show that all the variables are in acceptance range of correlation coefficients. Also, there is a positive and significant interrelationship between the study variables. These mean that there is no possibility of negative effects of multicollinearity (Bekhet and Al-Smadi 2015; Hamdi et al. 2014).

Table 1. Data Quality Test results

\begin{tabular}{|c|c|c|c|c|c|c|c|}
\hline Variable & $\mathrm{LSMI}_{\mathrm{t}}$ & $\mathrm{LGDP}_{\mathrm{t}}$ & LFDI $_{t}$ & $\mathrm{LM} 2_{\mathrm{t}}$ & $\mathrm{LIP}_{\mathrm{t}}$ & $\mathrm{LCPI}_{\mathrm{t}}$ & $\mathrm{EX}_{\mathrm{t}}$ \\
\hline Mean & 7.55 & 22.3 & 18.4 & 22.4 & 7.18 & 4.01 & 0.60 \\
\hline Median & 7.37 & 22.3 & 18.5 & 22.3 & 7.05 & 4.14 & 0.70 \\
\hline Maximum & 9.01 & 23.1 & 21.6 & 24.2 & 8.48 & 4.76 & 0.70 \\
\hline Minimum & 6.37 & 21.4 & 14.4 & 20.2 & 6.04 & 2.90 & 0.29 \\
\hline Std. Dev & 0.78 & 0.48 & 2.14 & 1.14 & 0.78 & 0.54 & 0.16 \\
\hline Skewness & 0.33 & 0.16 & 0.01 & -0.05 & 0.33 & -0.38 & -1.02 \\
\hline Kurtosis & 1.75 & 1.95 & 1.49 & 2.05 & 1.78 & 2.00 & 2.17 \\
\hline $\mathrm{J}-\mathrm{B}$ & 3.27 & 1.94 & 5.12 & 1.46 & 3.12 & 2.55 & 7.97 \\
\hline Probability & 0.19 & 0.37 & 0.30 & 0.48 & 0.20 & 0.27 & 0.11 \\
\hline $\mathrm{LSMI}_{\mathrm{t}}$ & 1.00 & & & & & & \\
\hline $\operatorname{LGDP}_{t}$ & 0.89 & 1.00 & & & & & \\
\hline $\mathrm{LFDI}_{\mathrm{t}}$ & 0.87 & 0.87 & 1.00 & & & & \\
\hline $\mathrm{LM} 2_{\mathrm{t}}$ & 0.89 & 0.90 & 0.84 & 1.00 & & & \\
\hline $\mathrm{LIP}_{\mathrm{t}}$ & 0.90 & 0.89 & 0.81 & 086 & 1.00 & & \\
\hline $\mathrm{LCPI}_{\mathrm{t}}$ & 0.86 & 0.90 & 0.79 & 0.88 & 0.86 & 1.00 & \\
\hline $\mathrm{EX}_{\mathrm{t}}$ & 0.68 & 0.71 & 0.62 & 0.76 & 0.70 & 0.87 & 1.00 \\
\hline
\end{tabular}

Note. J-B denotes Jarque-Bera statistic test for each model. The $\mathrm{H}_{0}$ of non- normality is rejected if the values of $\mathrm{J}-\mathrm{B}$ test $>10 \%$. 
Source: Output of the E-Views 7.2 econometric software.

The results of the ADF unit root test shows that all the variables are stationary at $\mathrm{I}(1)$ with the constant and trend at different significant levels (1\%,5\% and $10 \%)$, except that the $\mathrm{LGDP}_{\mathrm{t}}$ and $\mathrm{LFDI}_{\mathrm{t}}$ variables are stationary at $\mathrm{I}(0)$ and I(1). Also, these results are confirmed by the results of P-P unit root test. Moreover, the results of the KPSS unit root test indicate that all the variables are stationary at $\mathrm{I}(0)$ and $\mathrm{I}(1)$ with the constant and trend at $1 \%, 5 \%$ and $10 \%$ significant levels (see Table 2).

The results of ADF, P-P and KPSS tests are consistent with other many findings such as, Bekhetand Al-Smadi (2015) for Jordan;Bekhet and Matar (2013a) for Jordan; Bekhet and Mugableh (2012) for Malaysia;Ariff et al. (2012) for Canada; Ibrahim and Aziz (2003) for Malaysia. Generally, as the result of this tests confirmed that all the variables are stationary at I(1) the bounds F-statistics test would be utilized to test whether the variables are co-integrated or not.

Table 2. Stationary Test Results

\begin{tabular}{|c|c|c|c|c|c|c|c|}
\hline \multirow{2}{*}{ Variables } & \multicolumn{2}{|c|}{$\mathrm{ADF}$} & \multicolumn{2}{|c|}{ P.P } & \multicolumn{2}{|c|}{ KPSS } & \multirow{2}{*}{ Decision } \\
\hline & $\mathrm{I}(0)$ & $\mathrm{I}(1)$ & $\mathrm{I}(0)$ & $\mathrm{I}(1)$ & $\mathrm{I}(0)$ & $\mathrm{I}(1)$ & \\
\hline $\mathrm{LSMI}_{\mathrm{t}}$ & -2.07 & $-7.54^{\mathrm{a}}$ & -2.09 & $-7.57^{a}$ & $0.44^{\mathrm{a}}$ & $0.12^{\mathrm{c}}$ & $\mathrm{I}(1)$ \\
\hline $\mathrm{LGDP}_{\mathrm{t}}$ & $-3.61_{b}$ & $-5.70^{\mathrm{a}}$ & $-3.77_{b}$ & $-5.77^{\mathrm{a}}$ & $0.33^{\mathrm{a}}$ & $0.24^{\mathrm{b}}$ & $\mathrm{I}(1)$ \\
\hline LFDI $_{t}$ & $-3.37^{\mathrm{c}}$ & $-6.12^{a}$ & $-3.30_{c}$ & $-6.31^{a}$ & $0.56^{\mathrm{a}}$ & $0.30^{\mathrm{c}}$ & $\mathrm{I}(1)$ \\
\hline $\mathrm{LM} 2_{\mathrm{t}}$ & -2.14 & $-3.95^{b}$ & -2.34 & $-4.31^{\mathrm{a}}$ & $0.52^{\mathrm{a}}$ & $0.13^{\mathrm{c}}$ & $\mathrm{I}(1)$ \\
\hline $\mathrm{LIP}_{\mathrm{t}}$ & -3.16 & $-5.35^{\mathrm{a}}$ & -3.03 & $-5.07^{\mathrm{a}}$ & $0.62^{\mathrm{a}}$ & $0.18^{\mathrm{b}}$ & $\mathrm{I}(1)$ \\
\hline $\mathrm{LCPI}_{\mathrm{t}}$ & -2.20 & $-4.23^{b}$ & -2.76 & $-4.45^{\mathrm{a}}$ & $0.41^{\mathrm{a}}$ & $0.13^{\mathrm{c}}$ & $\mathrm{I}(1)$ \\
\hline $\mathrm{EX}_{\mathrm{t}}$ & -3.13 & $-4.42^{a}$ & -3.17 & $-5.84^{a}$ & $0.58^{\mathrm{a}}$ & $0.20^{\mathrm{b}}$ & $\mathrm{I}(1)$ \\
\hline
\end{tabular}

Notes. (1) a,b and c denotes statistically significance at 1\%,5\% and 10\% levels. (2) H0 for ADF and P-P tests are rejected if the variables have unit root. (3) H0 for KPSS test is rejected if the variables stationary. (4) The critical values for the ADF test are (-4.25), (-3.55) and (-3.21) at the 1\%, 5\% and 10\% significance levels, respectively. (5) The critical values for the P-P test are (-4.24), (-3.54) and $(-3.20)$ at the $1 \%, 5 \%$ and $10 \%$ significance levels, respectively. (6) The critical values for the KPSS test are (0.21), $(0.14)$ and $(0.11)$ at the $1 \%, 5 \%$ and $10 \%$ significance levels, respectively.

Source: Output of the E-Views 7.2 econometric software.

The results of the co-integration among the variables are shown in Table 3. These findings are determined by the F-statistic test.

Table 3. Co-integration Test Results

\begin{tabular}{|c|c|c|c|c|c|}
\hline \multirow{4}{*}{ Models } & \multirow{4}{*}{ F-statistic } & \multicolumn{3}{|c|}{ Bound Critical Values } & \multirow{4}{*}{ Decisions } \\
\hline & & \multicolumn{2}{|c|}{$1 \%$} & \multirow[t]{2}{*}{$5 \%$} & \\
\hline & & & $10 \%$ & & \\
\hline & & $\mathrm{I}(0), \mathrm{I}(1)$ & $\mathrm{I}(0), \mathrm{I}(1)$ & $\mathrm{I}(0), \mathrm{I}(1)$ & \\
\hline $\mathrm{LSMI}_{\mathrm{t}}$ & $5.19^{\mathrm{a}}$ & $3.50,5.12$ & $2.61,3.86$ & $2.21,3.31$ & Co-integration \\
\hline LGDP $_{t}$ & $4.17^{\mathrm{b}}$ & $3.50,5.12$ & $2.61,3.86$ & $2.21,3.31$ & Co-integration \\
\hline LFDI $_{t}$ & $3.74^{\mathrm{c}}$ & $3.50,5.12$ & $2.61,3.86$ & $2.21,3.31$ & Co-integration \\
\hline $\mathrm{LM} 2_{\mathrm{t}}$ & $2.61^{\mathrm{c}}$ & $3.50,5.12$ & $2.61,3.86$ & $2.21,3.31$ & Inconclusive \\
\hline $\mathrm{LIP}_{\mathrm{t}}$ & $2.89^{\mathrm{b}}$ & $3.50,5.12$ & $2.61,3.86$ & $2.21,3.31$ & Inconclusive \\
\hline $\mathrm{LCPI}_{\mathrm{t}}$ & $2.31^{\mathrm{c}}$ & $3.50,5.12$ & $2.61,3.86$ & $2.21,3.31$ & Inconclusive \\
\hline $\mathrm{EX}_{\mathrm{t}}$ & 1.78 & $3.50,5.12$ & $2.61,3.86$ & $2.21,3.31$ & No- integrated \\
\hline
\end{tabular}

Notes. (1) the F-statistics critical values were retrieved from (Narayan (2005), Case II). (2)a, b and c denotes statistically significance at $1 \%, 5 \%$ and $10 \%$ levels.

Source: Output of computed F-statistics values were obtained from Micro-fit 4.1 econometric software packages.

Table 3 shows that the $\mathrm{H} 0$ of no co-integration among the variables in the LSMI $\mathrm{I}_{\mathrm{t}}$ model is rejected at $1 \%$ significance level, while it rejected among the variables in $\mathrm{LGDP}_{\mathrm{t}}$ model at $5 \%$ significance level. Also, the $\mathrm{H} 0$ of no co-integration among variables in the $\mathrm{LFDI}_{\mathrm{t}}$ model is rejected at $10 \%$ significance level. Furthermore, the calculated F-statistics value in the $\mathrm{LM} 2_{\mathrm{t}}, \mathrm{LIP}_{\mathrm{t}}$, and $\mathrm{LCPI}_{\mathrm{t}}$ models falls in the range $\mathrm{I}(0) \leq \mathrm{F}$-statistics value $\leq \mathrm{I}(1)$ at the $5 \%$ and $10 \%$ significance levels respectively.In this case, the error correction term $\left(\mathrm{ECM}_{\mathrm{t}-1}\right)$ is a useful way of establishing the co-integration among the variables in the model and confirming it with past studies (Bekhet and Al-Smadi, 2016; Boutabba, 2014; Banerjee et al., 1998; Kremers et al., 1992). The results of the co-integration among the variables in the model $\left(\mathrm{LSMI}_{t}, \mathrm{LGDP}_{t}, \mathrm{LFDI}_{t}, \mathrm{LM} \mathrm{2}_{\mathrm{t}}, \mathrm{LIP}_{\mathrm{t}}, \mathrm{LCPI}_{\mathrm{t}}\right.$, and $\left.\mathrm{EX}_{\mathrm{t}}\right)$ are consistent with the findings of Bekhetand Al-Smadi, (2015) for Jordan; Bekhet and Matar (2013b) for Jordan; Bekhet and Mugableh (2012) for Malaysia; Ibrahim and Aziz (2003) for Malaysia. 


\subsection{Long and Short Run Results}

Several studies confirmed that, if the co-integration relationship among the variables in model is warranted then the long run and short run relationship between the study variables can be utilized (Bekhet and Al-Smadi, 2015; Khan et al., 2014; Uddin et al., 2013). However, the number of lag should be detected by depending on the lowest values of Hannan-Quinn information criterion (HQ), Schwarz information criterion (SC), Akaike information criterion (AIC) and Final prediction error(FPE) criteria. Also, it could use the likelihood ratio (LR) (sequential modified) test as a primary determinant of how many lags to be included (Pesaran et al., 1999; Granger, 1981). However, the results confirm that the optimal lag length $(\mathrm{k})$ is one lag.Table 4 presents the estimation of the long run and short run coefficients for the variables in the LSMItmodel. It shows a significance long-run and short run relationship among the variables at $1 \%, 5 \%$ and $10 \%$ levels.

Table 4. Long - Run and Short -Run Results

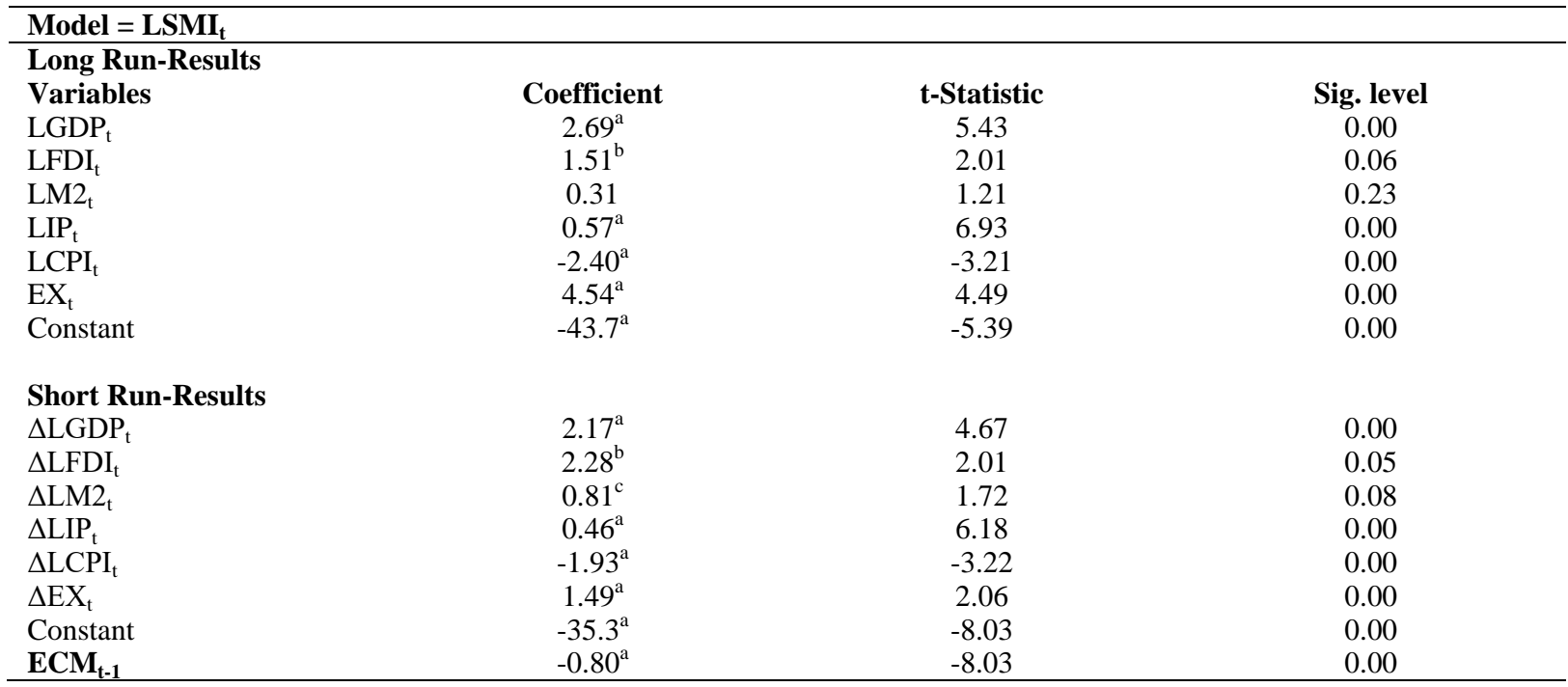

Notes. (1)a, b and c denote statistically significance at $1 \%, 5 \%$ and $10 \%$ levels, respectively; (2) multiplier test of residual serial correlation $=0.252$; (3) autoregressive conditional heteroskedasticity test $=2.82$; (4) Normality test $=3.03$; (5) RESET test using the square of the fitted values $=0.006$; (6) F-statistics $=12.93$; (7) $\mathrm{R}^{2}=76 \%$; (8) Durbin Watson $=1.96$.

Source: The Output of the Long, short-run and ECMt-1coefficients analyses were retrieved from Micro-fit 4.1 econometric software.

Table 4 shows that in the long run the all the coefficients results have a correct sign as discussed by several empirical studies see Bekhet and Matar (2013b) for Jordan; Bekhet and Mugableh (2012) for Malaysia; Ibrahim and Aziz (2003) for Malaysia. However, the results report that there is a positive relationship betweenLSMIt model and (LGDPt, LIPt and EXt) variables at 1\% significance level, which means that an increase of SMI would definitely lead to increasing the (GDP, IP and EX). This result is confirmed by the finance literature suggesting that emerging and developed financial markets might be able to promote economic growth (Bekhet and Matar, 2013b;Hussain, 2011;Gosnell and Nejadmalayeri, 2010; De Gregorio and Guidotti, 1995; Kirman, 1992; Chen et al., 1986).

Also, the result shows that the $\mathrm{LSMI}_{\mathrm{t}}$ model has a positive relationship with $\mathrm{LFDI}_{\mathrm{t}}$ variable at $5 \%$ significance level. This is because,FDI can fuel the development of financial systems through different channels. First, FDI can be conducive to the participation of firms in the capital markets, since foreign investors might want to finance part of their investment with external capital or might want to recover their investment by selling equity in capital markets. Second, given that foreign investors partly invest through purchasing existing equity, the liquidity of the stock markets will likely rise (Bekhet and Al-Smadi, 2014; Errunza, 1983). The result also, confirmed that the relationship between LSMIt model and LCPIt is negatively. These results are supported by Fama (1990); Geske and Roll (1983) and Chen et al. (1986), who hypothesized a similar significant relationship through the effects of macroeconomic variables on SMI and consistent with the findings of Bekhet and Matar (2013a) for Jordan; Bekhet and Mugableh (2012) for Malaysia.

Furthermore, Table 4 presents the results of the short-term dynamics equilibrium relationship between the LSMI $_{t}$ and the study variables. These results indicated that at $1 \%$ significance levels, the variables $\Delta \mathrm{LGDP}_{\mathrm{t}}, \Delta \mathrm{LIP}_{\mathrm{t}}$ and 
$\Delta \mathrm{EX}_{\mathrm{t}}$ are positively associated with $\Delta \mathrm{LSMIt}$ model. However, the $\Delta \mathrm{LFDIt}$ is positively associated with $\Delta \mathrm{LSMIt}$ model at $5 \%$ significance levels, while the $\Delta \mathrm{LM} 2 \mathrm{t}$ is positively associated with $\Delta \mathrm{LSMI}_{\mathrm{t}}$ model at $10 \%$ significance levels. Therefore, the result confirm that there is a negatively relationship between the $\Delta \mathrm{LCPI}_{\mathrm{t}}$ and $\Delta \mathrm{LSMI}_{\mathrm{t}}$ model at $1 \%$ significance levels.In addition, the coefficients of $\mathrm{ECM}_{\mathrm{t}-1}$ are significant with appropriate signs in absolute value with $-80 \%$. This implies that this model $\Delta$ LSMIt is corrected from the short-run towards the long-run equilibrium by $80 \%$. Also, this means that the long-run would be shortly corrected back by 1.2 year.

The results of stability tests of the LSMIt model, such as CUSUM and CUSUMQ are shown in Figure 4. The results of CUSUM and CUSUMQ tests confirmed that the co-integration estimates are reliable and consistent (Shahbaz et al., 2013) because both diagrams are within critical bounds at 5percent level of significance.
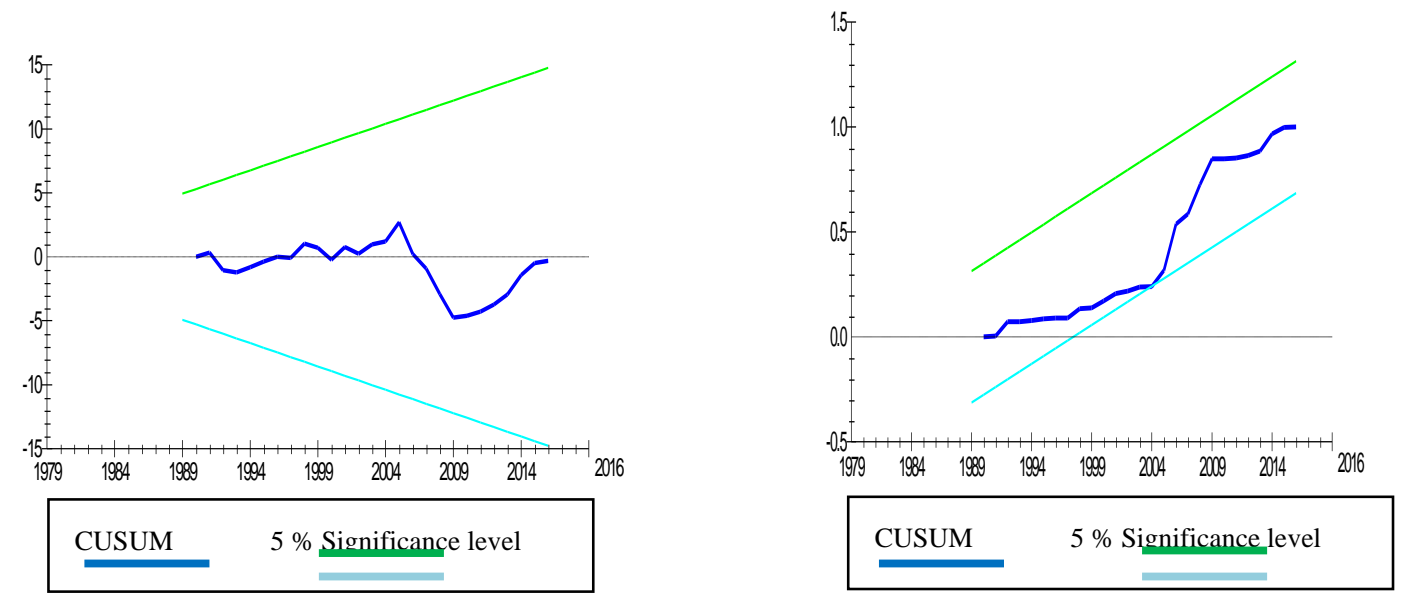

Figure 4. LSMIt model CUSUM and CUSUMQ for the (1978-2017) period

Note. (1)CUSUM is plot of cumulative sum of recursive residuals.

(2) CUSUMQ is plot of cumulative sum of squares of recursive residuals.

Source: The Output of CUSUM and CUSUMQ were retrieved from Micro-fit 4.1 econometric software.

\section{Conclusions}

The current study examines the long-run and short-run equilibrium relationships between stock market index and the macroeconomic variables (i.e., GDP, FDI, M2, IP, CPI, EX) in Jordan for the (1978-2017) period. Methodologically, it utilizes ADF and P.P tests for testing stationarity level. The bounds testing approach was employed to analyse the long-run and short-run relationships among models in the Jordanian economy.

In accumulation, the results showed evidence of long-run and short-run relationships among the SMI and the macroeconomic variables. In addition, the results of $\mathrm{ECM}_{\mathrm{t}-1}$ coefficients were significant with appropriate signs in absolute value with $-80 \%$. This implies that this model $\Delta \mathrm{LSMI}_{\mathrm{t}}$ is corrected from the short-run towards the long-run equilibrium by $80 \%$. Also, this means that the long-run would be shortly corrected back by 1.2 year.

In general, the results of this study are important for policy makers, foreign investors, corporations and academics since they are interested in the relationships among SMI and the macroeconomic variables. However, the results of this study recommend that the Jordanian policy makers have to pay more attention to the current regulation in the ASE and manage it well, thus ultimately helping financial development.Further study should be undertaken with an even wider scope in terms of macroeconomic variables such as interest rate, EO, oil prices and value traded.

\section{References}

Al-Bdour, J. M., \& Ahmad, A. G. (2012). Money Supply Role In Economic And Industrial Growth: The Case Of Jordan (1990-2010). European Scientific Journal, ESJ, 8(22).

Allahawiah, S., \& Al Amro, S., (2012). Factors affecting Stock Market Prices in Amman Stock Exchange: A Survey Study. European Journal of Business and Management, 4(8), 236-245.

Bekhet, H. A., \& Al-Smadi, R. W. (2014). Determining the causality relationships among FDI determinants: evidence from Jordan. International Journal of Sustainable Economy, 6(3), 261-274. https://doi.org/10.1504/IJSE.2014.063184 
Bekhet, H. A., \& Al-Smadi, R. W. (2015). Determinants of Jordanian foreign direct investment inflows: Bounds testing approach. Economic Modelling, 46, 27-35. https://doi.org/10.1016/j.econmod.2014.12.027

Bekhet, H. A., \& Al-Smadi, R. W. (2016). The dynamic causality between FDI inflow and its determinants in Jordan. International Journal of Economics and Business Research, 11(1), 26-47. https://doi.org/10.1504/IJEBR.2016.074427

Bekhet, H. A., \& Al-Smadi, R. W. (2017), Exploring the long-run and short-run elasticities between FDI inflow and its determinants in Jordan. International Journal of Business and Globalisation, 18(3), 337-362. https://doi.org/10.1504/IJBG.2017.083210

Bekhet, H. A., \& Matar, A. (2011). Analyzing risk-adjusted performance: Markwoitz and single index approaches in Amman Stock Exchange. International Conference on Management (ICM) Proceeding, Penang, Malaysia, Jun, 13-14/2011, pp. 305-321.

Bekhet, H. A., \& Mugableh, M. I. (2012). Investigating equilibrium relationship between macroeconomic variables and Malaysian stock market index through bounds tests approach. International Journal of Economics and Finance, 4(10), 69-81. https://doi.org/10.5539/ijef.v4n10p69

Bekhet, H.A., Matar, A. (2013), Co-integration and causality analysis between stock market prices and their determinates in Jordan. Economic Modelling, 35, 508-514. https://doi.org/10.1016/j.econmod.2013.07.012

Chen, N. F., Roll, R., \& Ross, S., (1986).Economic forces and the stock market. Journal of Business, 59, 383-403. https://doi.org/10.1086/296344

De Gregorio, J., \& Guidotti, P. E., (1995). Financial development and economic growth. World Development, 23(3), 433-448. https://doi.org/10.1016/0305-750X(94)00132-I

Fama, E. F. (1970). Efficient capital markets: A review of theory and empirical work. Journal of Finance, 25(2), 383-417. https://doi.org/10.2307/2325486

Gosnell, T., \& Nejadmalayeri, A., (2010).Macroeconomic news and risk factor innovations. Managerial Finance, 36(7), 566-582. https://doi.org/10.1108/03074351011050316

Hossain, M. A., Islam, A. F., \& Iji, P. A. (2013). Growth responses, excreta quality, nutrient digestibility, bone development and meat yield traits of broiler chickens fed vegetable or animal protein diets. South African Journal of Animal Science, 43(2), 208-218. https://doi.org/10.4314/sajas.v43i2.11

Hussain, S. M. (2011). Simultaneous monetary policy announcements and international stock markets response: an intraday analysis. Journal of Banking \& Finance, 35, 752-764.

https://doi.org/10.1016/j.jbankfin.2010.09.002

Ibrahim, M. H., \& Aziz, H. (2003). Macroeconomic variables and the Malaysian equity market: A view through rolling subsamples. Journal of economic studies, 30(1), 6-27. https://doi.org/10.1108/01443580310455241

Karim, B. A., \&Majid, M. S. (2010). Does trade matter for stock market integration? Studies in Economics and Finance, 27(1), 47-66. https://doi.org/10.1108/10867371011022975

Khan, M. A., Khan, M. Z., Zaman, K., Irfan, D., \& Khatab, H. (2014). Questing the three key growth determinants: Energy consumption, foreign direct investment and financial development in South Asia. Renewable Energy, 68, 203-215. https://doi.org/10.1016/j.renene.2014.02.021

Kirman, A. P. (1992). Whom or what does the representative individual represent? The Journal of Economic Perspectives 6(2), 117-136. https://doi.org/10.1257/jep.6.2.117

Kumar, A. (2011). An empirical analysis of causal relationship between stock market and macroeconomic variables in India. International Journal of Computer Science \& Management Studies, 11(1), 9-14.

Kyereboah, A., \&Agyire, K. (2008). Impact of macroeconomic indicators on stock market performance: The case of the Ghana Stock Exchange. Journal of Risk Finance, 9(4), 365-378. https://doi.org/10.1108/15265940810895025

Li, Y. D., Iscan, T. B., \&Xu.K. (2010). The impact of monetary policy shocks on stock prices: Evidence from Canada and the United States. Journal of International Money and Finance, 29, 876-896. https://doi.org/10.1016/j.jimonfin.2010.03.008

Naik, P. K., \&Padhi, P. (2012). Interaction of Macroeconomic Factors and Stock Market Index: Empirical Evidence from Indian Data.

Otchere, I., Soumare, I., \& Yourougou, P. (2011), FDI and Financial market development in Africa. Sprott School 
of Business Carleton University, Ottawa (ON), Canada, 1-30.

Pal, K., \& Mittal, R. (2011). Impact of macroeconomic indicators on Indian capital markets. The Journal of Risk Finance, 12(2), 84-97. https://doi.org/10.1108/15265941111112811

Pesaran, M. H., Shin, Y., \& Smith, R. J. (2001), Bounds testing approach to the analysis of level relationships. Journal of Applied Econometrics, 16, 289-326. https://doi.org/10.1002/jae.616

Pesaran, M. H., Shin, Y., \& Smith, R. P. (1999), Pooled mean group estimation of dynamic heterogeneous panels. Journal of the American Statistical Association, 94(446), 621-634. https://doi.org/10.1080/01621459.1999.10474156

Phillips, P. C., Perron, P. (1988), Testing for a unit root in time series regression. Biometrika, 75, 335-346. https://doi.org/10.1093/biomet/75.2.335

Rahman, A. A., Sidek, N. Z. M., \&Tafri, F. H. (2009). Macroeconomic determinants of Malaysian stock market. African Journal of Business Management, 3(3), 95-106.

Rangel, J. G. (2011). Macroeconomic news, announcements, and stock market jump intensity dynamics. Journal of Banking \& Finance, 35(5), 1263-1276. https://doi.org/10.1016/j.jbankfin.2010.10.009

Ross, S. (1976). The Arbitrage Theory of Capital Asset Pricing. Journal of Economic Theory, 13(3), 341-360. https://doi.org/10.1016/0022-0531(76)90046-6

Sharpe, W. F. (1964). Capital asset prices: A theory of market equilibrium under conditions of risk. The journal of finance, 19(3), 425-442.

UNCTAD. (2011), World investment prospects survey, United Nations Conference on Trade and Development: available on line at: http://www.unctad-docs.org/files/UNCTAD-WIR2011-Full-en.pdf.

World Bank. (2013), International bank for reconstruction and development and international finance corporation: available online at: http://www.albankaldawli.org.

\section{Copyrights}

Copyright for this article is retained by the author(s), with first publication rights granted to the journal.

This is an open-access article distributed under the terms and conditions of the Creative Commons Attribution license (http://creativecommons.org/licenses/by/4.0/). 